\title{
Reasons for the Removal of Tevatron Dipoles From the Tunnel: A Summary
}

\author{
Norman M. Gelfaind \\ Fermi National Accelerator Laboratory \\ P.O. Box 500, Batavia, Illinois 60510
}

\section{DISCLAIMER}

This report was prepared as an account of work sponsored by an agency of the United States Government. Neither the United States Government nor any agency thereof, nor any of their employees, makes any warranty, express or implied, or assumes any legal liability or respunsibility for the accuracy, completeness, or usefulness of any information, apparatus, product, or process discloied, or represents that its use would not infringe privately owned rights. Reference herein to iny specific commercial product, process, or service by trade name, trademark, manufacturer, or otherwise does not necessarily constitute or imply its endorsement, recommendation, or favoring by the United States Government or any agency thereof. The views and opinions of authors expressed herein do not necessarily state or reflect those of the United States Government or any agency thereof.

August 1992

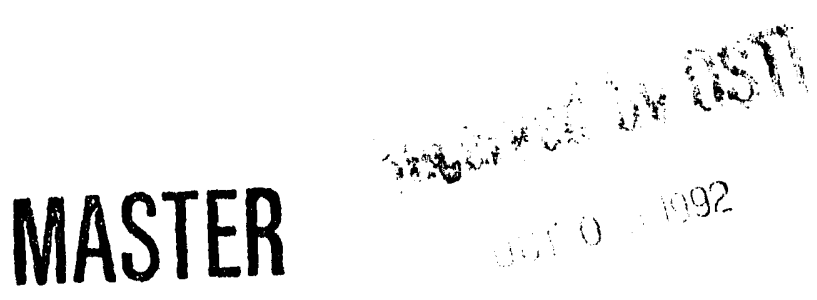




\section{Disclaimer}

This report was prepared as an account of work sponsored by an agency of the United States Government. Neither the United States Government nor any agency thereof, nor any of their employees, makes any warranty, express or implied, or assumes any legal liability or responsibility for the accuracy, completeness, or usefulness of any information, apparatus, product, or process disclosed, or represents that its use would not infringe privately owned rights. Reference herein to any specific commercial product, process, or service by trade name, trademark, manufacturer, or otherwise, does not necessarily constitute or imply its endorsement, recommendation, or favoring by the United States Government or any agency thereof. The views and opinions of authors expressed herein do not necessarily state or reflect those of the United States Government or any agency thereof. 


\section{Reasons for the Removal of Tevatron Dipoles From The Tunnel: A Summary}

Norman M. Gelfand*

September 8, 1992

\section{Summary}

The commissioning of the Tevatron was completed in 1983 and immediately thereafter the experimental physics program began. The initial program involved using the Tevatron, first at $400 \mathrm{GeV}$ and then at $800 \mathrm{GeV}$ to supply beam for fixed target experiments. Beginning in 1985 the collider program has alternated with the fixed target program. The collider program runs with $900 \mathrm{GeV}$ protons and anti-protons. In the period since 1983 , in addition to providing beam for the High Energy Physics program, we have had to shut down the Tevatron for modifications to the lattice (as dictated by the demands of the physics program) and for repairs to the magnets. These repairs have resulted in an accelerator that operates with high efficiency and reliability.

\section{The Performance of the Tevatron Dipoles}

The Tevatron, the worlds first high energy accelerator to be built of superconducting ruagnets, was constructed at the Fermi National Accelerator Laboratory. Construction was completed in 1983. The Tevatron contains 774 full length superconducting dipoles.

"Work supported by the U.S. Department of Energy under contract No. DE-AC0276CHO3000 
During the period of operation of the Tevatron, beginning with the end of commissioning in 1983, and continuing over more than 8 years, (the operational history of the Tevatron is found in table I) it has been necessary to replace approximately 175 of these dipole magnets. When a magnet was replaced a form was filled out giving a reason for the replacement. It generally described the physical symptom, e.g., rupture, rather than the underlying cause for the failure. The reason for failure often was discovered only after the analysis of several magnets showing similar failure modes. The data on the forms was entered into a data base. Unfortunately the results of the failure analyses were not systematically collected. This report is based on information recovered from the data base. Thus the conclusions as to failure modes are not taken from engineering reports but represent what $I$ feel is informed opinion.

Magnets were replaced for a variety of reasons. These ranged from replacing good magnets to reduce harmonic driving terms (12 magnets) to replacements due to massive failure of the magnets because of broken strands in the superconducting cable or shorts (30 magnets). Tevatron magnets have also been replaced for reasons having nothing to do with the design or fabrication of the magnets. As an example, we have had to replace Tevatron magnets when a Main Ring magnet, located above the Tevisun, fell off its cribbing and struck several Tevatron magnets.

Early in the life of the Tevatron, magnets suffered massive failures due to shorts. These failures often resulted in ruptves of the vacuum and this was generally given as the reason for failure of the magnet. Analysis of these magnets showed that the problem was in the design and fabrication of the magnets; the length of superconducting cable from the external connections to the coil assembly was not properly secured. This led, during ramping of the current, to motion of the cable, work hardening and eventual failure. This problem is obviously worse during fixed target operation. Once the reason for the failures was recognized, it was possible to to correct the problem in the magnets which had not yet failed, by securing their leads. This rework of the magnets was done without removing them from the tunnel. During the rework some of the tunnel magnets were observed to have broken strands of superconducting cable. These magnets were replaced as this problem could not be fixed in the tunnel. Since the reworks were completed, this failure mode has not reoccurred.

Magnets have also failed due to leaks and hi-pot failures that developed 
after thermal cycling (approximately 90 magnets). In some cases, the leaks have been caused by movement of the G10 blocks holding the superconducting leads or by insufficient clearance between the blocks and the cryostat. During the cool down of the magnets, this could stress the welds and cause leaks. Hi-pot failures have also resulted from unwinding of the the kapton insulation around the beam tube. Most of these failures occurred during the cool down of the magnets following a period wherc they were warm. Since the leak check, hi-pot tests and the following cool down of the Tevatron generally proceeds one house at a time, most of these failures were found when the Tevatron was shut down. These problems have also been fixed during the rework periods.

About 35 magnets have been replaced for poor quench performance as we have attempted to raise the energy of the Tevatron. Magnets identified with quench problems were not always removed immediately but were replaced during scheduled down times. The reason for these failures is probably poor cable, in the magnets with low serial numbers, and poor splices, in the later magnets.

The reasons for magnet replacement are summarized in tables II and III and figure 1.

After the original design flaws were recognized and corrected, the Tevatron magnets have proven to be extremely reliable. There is no reason to believe that they should not give many more years of reliable service.

\section{Acknowledgements}

I wish to thank John Crawford and Jay Theilacker for providing me with information needed in the preparation of this report. 
Table I

Tevatron Operations History

\begin{tabular}{|l|l|l|}
\hline $\begin{array}{l}\text { Start } \\
\text { Date }\end{array}$ & $\begin{array}{l}\text { End } \\
\text { Date }\end{array}$ & Description \\
\hline $7 / 3 / 83$ & $9 / 26 / 83$ & Accelerated and Extracted 512 Gev Beam, \\
& & $700 \mathrm{GeV}$ Storage. \\
$9 / 27 / 83$ & $2 / 17 / 84$ & $400 \mathrm{GeV}$ fixed target. \\
$2 / 18 / 84$ & $3 / 11 / 84$ & Studies, 800 GeV Extraction and storage tests. \\
$3 / 12 / 84$ & $7 / 16 / 84$ & $800 \mathrm{GeV}$ fixed target. \\
$7 / 17 / 84$ & $1 / 13 / 85$ & Warm up- TC Dipole Repair,D0 overpass \\
& & construction, and anti-proton source \\
& & construction; startup. \\
$1 / 14 / 85$ & $8 / 29 / 85$ & $800 \mathrm{GeV}$ fixed target. \\
$8 / 30 / 95$ & $9 / 12 / 83$ & Pbar source commissioning. \\
$9 / 13 / 85$ & $10 / 14 / 85$ & $800 \mathrm{GeV}$ collider. \\
$10 / 15 / 85$ & $7 / 31 / 86$ & Warm up for B0 overpass and D0 experimental \\
& & hall construction. \\
$8 / 1 / 86$ & $2 / 1 / 87$ & Accelerator startup. \\
$2 / 2 / 87$ & $5 / 11 / 87$ & $900 \mathrm{GeV}$ collider. \\
$5 / 12 / 87$ & $6 / 14 / 87$ & Switch over to fixed target physics. \\
$6 / 15 / 87$ & $2 / 15 / 88$ & $800 \mathrm{GeV}$ fixed target. \\
$2 / 16 / 88$ & $5 / 31 / 88$ & Warm up- dipole repair,D0 overpass, and B0 \\
& & shielding. \\
$6 / 1 / 88$ & $6 / 19 / 88$ & Accelerator startup. \\
$6 / 20 / 88$ & $5 / 31 / 89$ & $900 \mathrm{GeV}$ collider. \\
$6 / 1 / 89$ & $7 / 30 / 89$ & Studies. \\
$8 / 1 / 89$ & $2 / 11 / 90$ & Warm up for dipole repair. \\
$2 / 12 / 90$ & $8 / 27 / 90$ & $800 \mathrm{GeV}$ fixed target. \\
$8 / 28 / 90$ & $7 / 15 / 91$ & Warm up for installation of new low beta at B0. \\
$7 / 16 / 91$ & $1 / 8 / 92$ & $800 \mathrm{GeV}$ fixed target. \\
$1 / 9 / 92$ & $5 / 31 / 92$ & Warm up- Shielding modifications, installation \\
& & of low beta at Do. \\
$6 / 1 / 92$ & $8 / 24 / 92$ & $900 \mathrm{Gev}$ collider. \\
\hline
\end{tabular}


Table II

Count of Reported Reasons for Failure

\begin{tabular}{|l|r|}
\hline Reason for Failure & Number \\
\hline Leaks & 61 \\
Poor quench & 34 \\
Hi-pot & 22 \\
Ground fault & 12 \\
Lattice match & 12 \\
Broken strands & 11 \\
Lead failure/short & 7 \\
External causes & 7 \\
Other & 4 \\
Rupture & 4 \\
Possible damage & 3 \\
Mechanical failure & 1 \\
\hline Total & 178 \\
\hline
\end{tabular}


Table III

Failures in Each Operating Period

\begin{tabular}{|c|c|c|c|c|c|}
\hline $\begin{array}{l}\text { Start } \\
\text { Date }\end{array}$ & $\begin{array}{l}\text { End } \\
\text { Date }\end{array}$ & $\begin{array}{l}\text { Tevatron } \\
\text { Condition }\end{array}$ & $\begin{array}{l}\text { Number } \\
\text { Replaced }\end{array}$ & Reason & Number \\
\hline $7 / 3 / 83$ & $9 / 26 / 83$ & Not HEP & 2 & $\begin{array}{l}\text { Leaks } \\
\text { External causes }\end{array}$ & $\begin{array}{l}1 \\
1\end{array}$ \\
\hline $9 / 27 / 83$ & $2 / 17 / 84$ & Fixed target & 0 & & \\
\hline $2 / 18 / 84$ & $3 / 11 / 84$ & Not HPP & 0 & & \\
\hline $3 / 12 / 84$ & $7 / 16 / 84$ & Fixed target & 7 & $\begin{array}{l}\text { Ground fault } \\
\text { Lead failure/short }\end{array}$ & $\begin{array}{l}5 \\
2\end{array}$ \\
\hline $7 / 17 / 84$ & $1 / 13 / 85$ & Not HEP & 17 & $\begin{array}{l}\text { Hi-pot } \\
\text { Leaks } \\
\text { External causes } \\
\text { Poor quench } \\
\text { Lattice match } \\
\text { Other }\end{array}$ & $\begin{array}{l}7 \\
4 \\
3 \\
1 \\
1 \\
1\end{array}$ \\
\hline $1 / 14 / 85$ & $8 / 29 / 85$ & Fixed target & 3 & $\begin{array}{l}\text { Poor quench } \\
\text { Leaks }\end{array}$ & $\begin{array}{l}2 \\
1\end{array}$ \\
\hline $8 / 30 / 85$ & $9 / 12 / 85$ & Not HEP & $\overline{3}$ & $\begin{array}{l}\text { Leaks } \\
\text { Rupture } \\
\text { Possible damage }\end{array}$ & $\begin{array}{l}1 \\
1 \\
1\end{array}$ \\
\hline $9 / 13 / 85$ & $10 / 14 / 85$ & Fixed target & 5 & $\begin{array}{l}\text { Poor quench } \\
\text { External causes }\end{array}$ & $\begin{array}{l}3 \\
2\end{array}$ \\
\hline $10 / 15 / 85$ & $7 / 31 / 86$ & Not HEP & 35 & $\begin{array}{l}\text { Poor quench } \\
\text { Hi-pot } \\
\text { Leaks } \\
\text { Lattice match }\end{array}$ & $\begin{array}{r}15 \\
8 \\
6 \\
6\end{array}$ \\
\hline
\end{tabular}


Table III

Failures in Each Operating Period

\begin{tabular}{|c|c|c|c|c|c|}
\hline $\begin{array}{l}\text { Start } \\
\text { Date }\end{array}$ & $\begin{array}{l}\text { End } \\
\text { Date }\end{array}$ & $\begin{array}{l}\text { Tevatron } \\
\text { Condition }\end{array}$ & $\begin{array}{r}\text { Number } \\
\text { Replaced }\end{array}$ & Reason & Number \\
\hline $8 / 1 / 86$ & $2 / 1 / 87$ & Not HEP & 14 & $\begin{array}{l}\text { Leaks } \\
\text { Poor quench } \\
\text { Hi-pot } \\
\text { Ground fault } \\
\text { Lattice match } \\
\text { Other } \\
\text { Possible damage }\end{array}$ & $\begin{array}{l}7 \\
2 \\
1 \\
1 \\
1 \\
1 \\
1\end{array}$ \\
\hline $2 / 2 / 87$ & $5 / 11 / 87$ & Collider & 2 & $\begin{array}{l}\text { Leaks } \\
\text { Broken strands }\end{array}$ & $\begin{array}{l}1 \\
1\end{array}$ \\
\hline $5 / 12 / 87$ & $6 / 14 / 87$ & Not HEP & 2 & $\begin{array}{l}\text { Poor quench } \\
\text { Leaks }\end{array}$ & $\begin{array}{l}1 \\
1\end{array}$ \\
\hline $6 / 15 / 87$ & $2 / 15 / 88$ & Fixed target & 26 & $\begin{array}{l}\text { Leaks } \\
\text { Ground fault } \\
\text { Poor quench } \\
\text { Lead failure/short } \\
\text { Lattice match } \\
\text { Rupture } \\
\text { Hi-pot } \\
\text { Possible damage }\end{array}$ & $\begin{array}{l}7 \\
5 \\
4 \\
4 \\
2 \\
2 \\
1 \\
1\end{array}$ \\
\hline $2 / 16 / 88$ & $5 / 31 / 88$ & Not HEP & 18 & $\begin{array}{l}\text { Leaks } \\
\text { Broken strands } \\
\text { Other } \\
\text { Hi-pot } \\
\text { Lead failure/short } \\
\text { Lattice match } \\
\text { Mechanical failure }\end{array}$ & $\begin{array}{l}6 \\
6 \\
2 \\
1 \\
1 \\
1 \\
1\end{array}$ \\
\hline
\end{tabular}




\section{Lable lll}

Failures in Each Operating Period

\begin{tabular}{|c|c|c|c|c|c|}
\hline $\begin{array}{l}\text { Start } \\
\text { Date }\end{array}$ & $\begin{array}{l}\text { End } \\
\text { Date }\end{array}$ & $\begin{array}{l}\text { Tevatron } \\
\text { Condition }\end{array}$ & $\begin{array}{l}\text { Number } \\
\text { Replaced }\end{array}$ & Reason & Number \\
\hline $6 / 1 / 88$ & $6 / 19 / 88$ & Not HEP & 0 & & \\
\hline $6 / 20 / 88$ & $5 / 31 / 89$ & Collider & 8 & $\begin{array}{l}\text { Poor quench } \\
\text { Leaks } \\
\text { Rupture }\end{array}$ & $\begin{array}{l}4 \\
3 \\
1 \\
\end{array}$ \\
\hline $6 / 1 / 89$ & $7 / 30 / 89$ & Not HEP & 6 & $\begin{array}{l}\text { Leaks } \\
\text { Poor quench } \\
\text { Broken strands }\end{array}$ & $\begin{array}{l}3 \\
2 \\
1 \\
\end{array}$ \\
\hline $8 / 1 / 89$ & $2 / 11 / 90$ & Not HEP & 25 & $\begin{array}{l}\text { Leaks } \\
\text { Hi-pot } \\
\text { Broken strands } \\
\text { Lattice match } \\
\text { External causes }\end{array}$ & $\begin{array}{r}17 \\
3 \\
3 \\
1 \\
1\end{array}$ \\
\hline $2 / 12 / 90$ & $8 / 27 / 90$ & Fixed target & 2 & Leaks & 2 \\
\hline $8 / 28 / 90$ & $7 / 15 / 9 !$ & Not HEP & 0 & & \\
\hline $7 / 16 / 91$ & $1 / 8 / 92$ & Fixed target & 3 & $\begin{array}{l}\text { Leaks } \\
\text { Hi-pot } \\
\text { Ground fault }\end{array}$ & $\begin{array}{l}1 \\
1 \\
1\end{array}$ \\
\hline $1 / 9 / 92$ & $5 / 31 / 92$ & Not HEP & 0 & & \\
\hline $6 / 1 / 92$ & $8 / 24 / 92$ & Collider & 0 & & \\
\hline
\end{tabular}




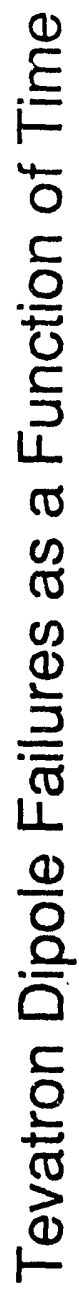

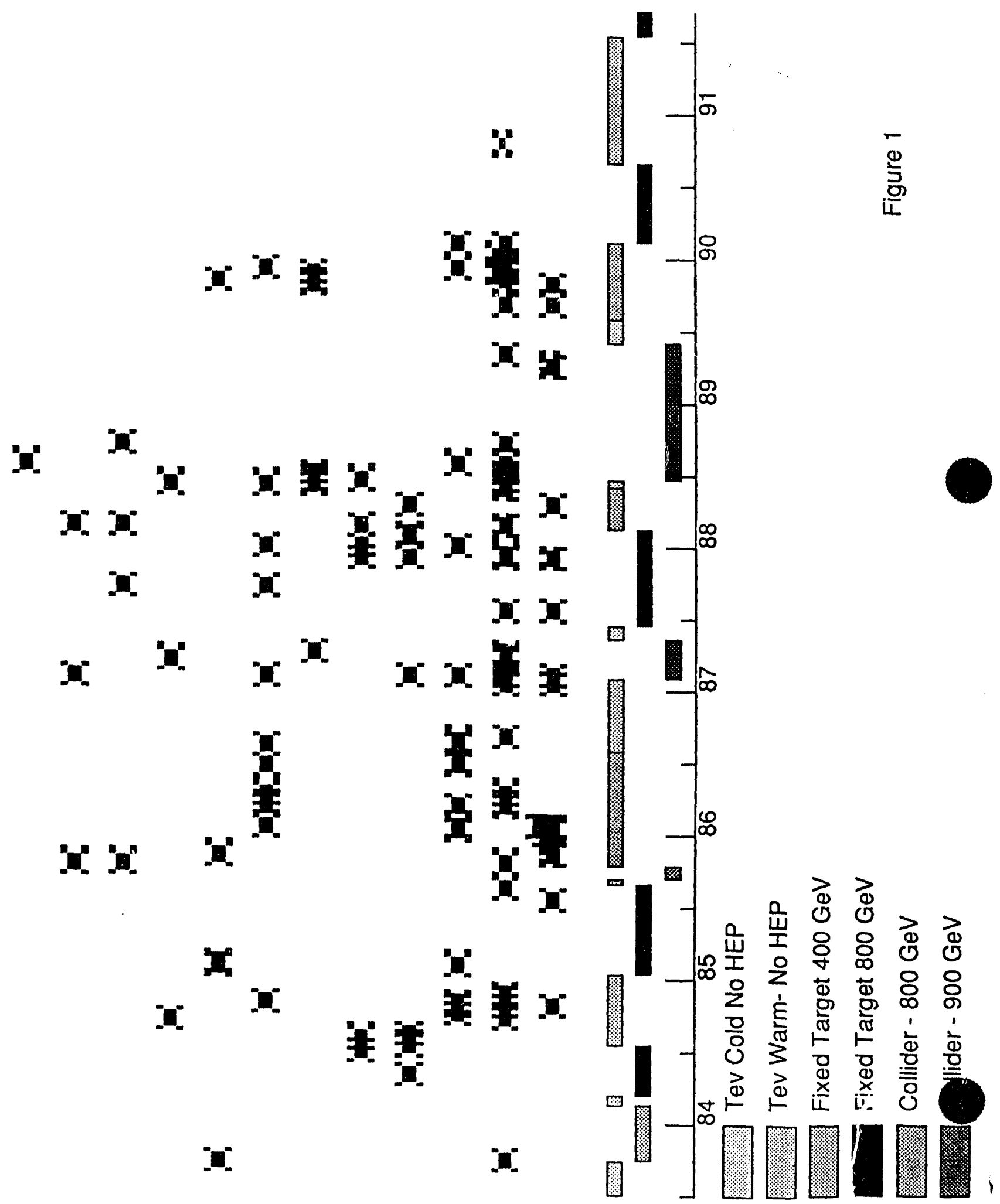



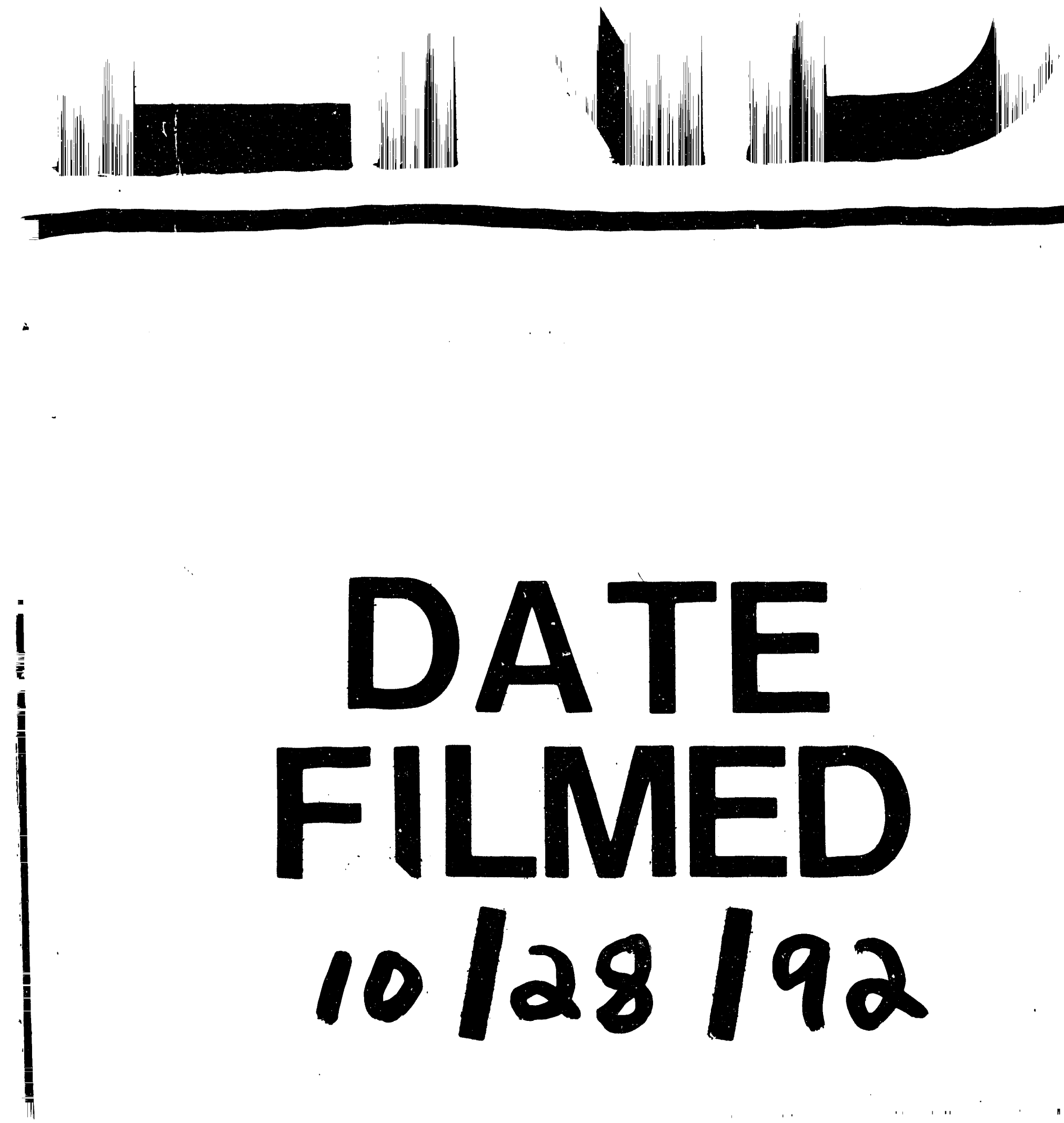
.

\section{.}

. 